\title{
The Effect of Breast Self-Examination (BSE) Class on Knowledge and Practice of Breast Self-Examination among Adolescent Girls
}

\author{
Shinta Novelia ${ }^{1 *}$, Yenny Aulya ${ }^{2}$, Elsa Regiyanti ${ }^{3}$ \\ 1,2,3Midwifery Department, Universitas Nasional Jakarta, Indonesia; shinta.novelia@civitas.unas.ac.id (Corresponding Author)
}

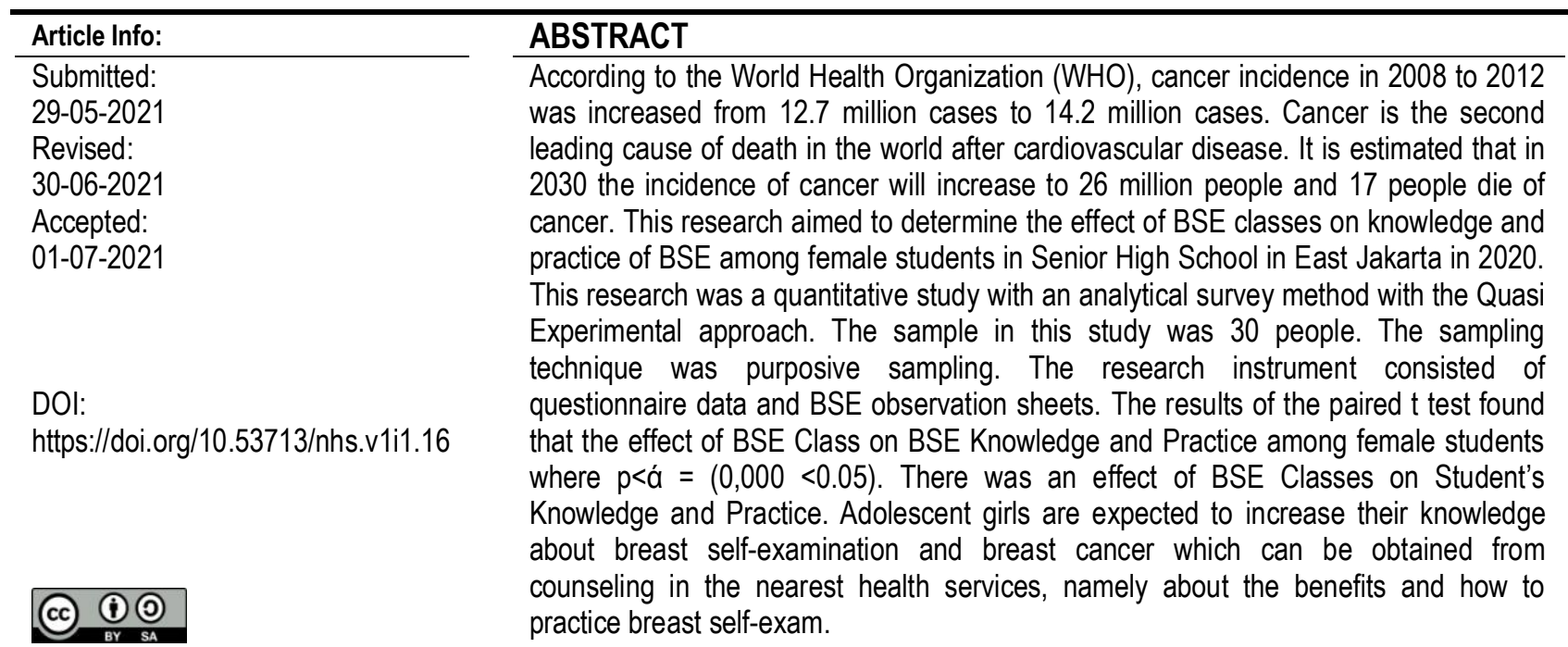

This work is licensed under CC BY-SA License.

Keywords: BSE Knowledge; BSE Practices; female students.

\section{INTRODUCTION}

According to the World Health Organization (WHO), the incidence of cancer from 2008 to 2012 has increased from 12.7 million cases to 14.2 million cases. Cancer is the second leading cause of death in the world after cardiovascular disease. It is estimated that by 2030 the incidence of cancer will increase to 26 million people and 17 people will die from cancer (Pusdatin Kemenkes RI, 2015). Breast cancer (mammae carcinoma) is a disease in which malignant (cancer) cells are detected in the breast tissue. These cancer cells then spread in tissues or organs and to other parts of the body (Katikawati, 2013).

Based on Global Burden Cancer (Globocan) data, the International Agency for Research on Cancer (IARC), it is known that in 2012 breast cancer in the female population still ranked first in new cases and deaths due to cancer, which were $43.3 \%$ and $12.9 \%$. Globocan also estimated the incidence of cancer in Indonesia was 134 per 100,000 population. This estimate was not much different from the Riskesdas 2013 which found the prevalence of cancer in Indonesia was 1.4 per 1000 population or around 330,000 people. Meanwhile, in DKI Jakarta, the prevalence of breast cancer in 2013 was 1.9 per 1000 population (Ministry of Health, 2015).

The causative factor is thought to be due to lifestyle changes such as eating fast food habits, frequent exposure to radiation from electronic media and changes in environmental conditions (YKPJ, 2011). Another cause of the high incidence of breast cancer is the limited knowledge of the public about the dangers of breast cancer, early signs, risk factors and ways to overcome them (Indonesian Cancer Foundation, 2012). One of the efforts to improve the practice of BSE is through counseling with BSE training. Health education is a health promotion activity in the form of providing health information or messages to provide or increase knowledge and attitudes about health in order to facilitate healthy behavior (Notoatmodjo, 2014).

BSE is a breast self-examination that aims to determine whether or not there is cancer in a woman's breast. This examination was carried out using a mirror and was carried out by women aged 20 years and over (Olfah et al., 2017). The benefits of doing BSE is that it can increase the life expectancy of breast cancer sufferers, because it can be detected early and this method can be done easily, cheaply, and simply. On breast self-examination, almost $85 \%$ of abnormal lumps were found by the patient himself through examinations with the right steps (Nisman, 2011). The low 
knowledge of women about breast cancer will slow down efforts to prevent early detection so that many women are less interested in making early detection efforts in breast cancer prevention (Suastina, 2013).

Based on the results of research conducted by Syaiful \& Aristantia (2016), it showed that there were differences in the skills of students in carrying out BSE examination. So that the results of this study can be concluded that health education through the demonstration method of BSE practice skills affects BSE practice skills at SMA Muhammadiyah 1 Metro. While the results of research conducted in Sukoharjo Regency with female adolescent respondents aged 12-22 years, it was found that 133 respondents $(65.8 \%)$ had less knowledge about how to practice BSE, 92 respondents (45.5\%) had less knowledge about BSE procedures, 95 respondents (47\%) had less knowledge about BSE time, and 94 respondents (46.5\%) had less knowledge about BSE results (Handayani \& Sudarmiati, 2012). From the result of interviews conducted by researchers on January 8, 2020 at SMAN " $x$ " Jakarta through questions and answers with 10 students, 1 of whom had heard about BSE but did not know how to do BSE, 9 of them didn't even know about BSE and how to do BSE. It was because there is no curriculum that provides material about BSE and there has never been any research on knowledge and practice of BSE in schools, therefore the author intends to research about the effect of bse classes on bse knowledge and practices for students at SMAN " $x$ " in East Jakarta. It is necessary to provide information regarding BSE knowledge, to increase the awareness of students to carry out early breast cancer screening and in the future similar examinations can continue to be carried out with full awareness of themselves.

\section{METHOD}

The research method used in this study was a Quasi Experimental Design. This study used a One Group Pretest Posttest Design. This design does not have a comparison group (control), but a first observation (pretest) has been carried out which allows testing the changes that occur after the experiment (Notoatmodjo, 2010). The population in this study was 65 students in class X IPS 1 and X IPS 2 at SMAN "x" in Jakarta 2020. The sample in this study was 30 students of class X IPS 1 and X IPS 2 which had been found by simple random sampling. The research location was conducted at SMAN "x" in East Jakarta in December 2019 - January 2020.

The instrument used to obtain data in this study was a questionnaire sheet that had been validated in previous research (Hasanah, 2016). In addition, this research used the observation sheet to measure the practice of doing BSE consists of 15 steps to do BSE. This observation sheet has been validated by the expert. Data analysis in this study was univariate and bivariate analysis. Univariate and bivariate analysis were carried out to analyze the data.

\section{RESULT}

Table 1. Knowledge related to BSE before and after intervention

\begin{tabular}{ccccc}
\hline \multirow{2}{*}{ Knowledge } & \multicolumn{2}{c}{ Before intervention } & \multicolumn{2}{c}{ After intervention } \\
\cline { 2 - 5 } & $\mathrm{n}$ & $\%$ & $\mathrm{n}$ & $(\%)$ \\
\hline Good & 4 & 13.3 & 16 & 53.3 \\
\hline Poor & 26 & 86.7 & 14 & 46.7 \\
\hline Total & 30 & 100 & 30 & 100 \\
\hline
\end{tabular}

Based on table 1, it can be concluded that majority of the respondents had a poor level of knowledge (13.3\%) before the intervention and majority of the respondents had a good level of knowledge (53.5\%) after the intervention.

Table 2. Practice of BSE before and after intervention

\begin{tabular}{|c|c|c|c|c|}
\hline \multirow{2}{*}{ Practice } & \multicolumn{2}{|c|}{ Before intervention } & \multicolumn{2}{|c|}{ After intervention } \\
\hline & $n$ & $\%$ & $n$ & $\%$ \\
\hline Good & 2 & 6.7 & 16 & 53.3 \\
\hline Less & 28 & 93.3 & 14 & 46.7 \\
\hline Total & 30 & 100 & 30 & 10 \\
\hline
\end{tabular}

Based on table 2, it can be concluded that majority of the respondents had a less level of practice (93.3\%) before the intervention and majority of the respondents had a good level of practice $(53.5 \%)$ after the intervention. 
Table 3. The differences of knowledge before and after intervention

\begin{tabular}{clcc}
\hline \multicolumn{1}{c}{ Variables } & \multicolumn{1}{c}{ Intervention } & Mean & $p$ \\
\hline \multirow{2}{*}{ Knowledge } & Before & 5.17 & 0.005 \\
\cline { 2 - 3 } & After & 7.53 & \\
\hline \multirow{2}{*}{ Practice } & Before & 9.47 & 0.005 \\
\cline { 2 - 3 } & After & 11.80 & \\
\hline
\end{tabular}

The table 3 showed that the mean of knowledge before intervention was 5.16 and increased to 7.53 after intervention. The results of paired sample $t$ test showed that there was a significantly differences on knowledge before and after intervention $(p=0.005)$. furthermore, the mean of practice before the intervention was 9.47 and increased to 11.8 after the intervention. There was a significantly differences on practice of BSE before and after intervention $(p=$ 0.005).

\section{DISCUSSION}

The high level of knowledge will have an impact on the behavior change process that will be carried out in connection with the problems it faces. Someone who has good level of knowledge in a matter will easily accept better behavior, on the other hand, someone who has low knowledge will find it difficult to accept new behavior well (Notoatmodjo, 2010). Previous research found there was a significant relationship between knowledge and practice of BSE (Sulistiani, 2015). The better the value of student's knowledge about awareness, the better the implementation of awareness. This is related to the research results which found the knowledge is better after intervention, so do the practice.

Knowledge is the result of human sensing or the result of knowing someone about an object through their five senses (Nasution, 2013). Teknologi pengetahuan. Dies Fasilkom-TI USU.). The five human senses are used for sensing objects, namely sight, hearing, smell, taste and touch. When sensing to produce knowledge is influenced by the intensity of attention and perception of the object. A person's knowledge is mostly obtained through the sense of hearing and the sense of sight. Good knowledge will make it easier to carry out BSE which aims to prevent the occurrence of more severe breast cancer so that the sufferer can be treated as soon as possible.

These results found that the majority of respondents had less knowledge about BSE. Researchers assumed this may be related to the respondents' lack of interest in finding information about breast cancer, how to check BSE and the lack of awareness of breast cancer.Based on the observations of researchers, some respondents said that there was no desire to know about BSE due to a lack of knowledge, so respondents asked the researcher about the effect of providing information about BSE on increasing knowledge. The best way for respondents to do BSE is to get good knowledge about BSE. By conducting counseling, one of which can trigger respondents to find out the effects of breast cancer and early detection methods, so that the curiosity to do BSE is greater.

Action is a person's behavior to implement or practice what he knows or his attitude is considered good. Visual stimuli (vision) and audio (hearing) can affect a person's interest in improving one's actions for the better (Notoatmodjo, 2012). The results of this study are in line with Yufdel et al., (2017) which states that the majority ofrespondents do not practice BSE, which indicates that respondents still lack interest in preventing breast cancer by performing breast selfexamination (BSE). Based on the observations of the researchers, some respondents said that there was no desire to practice BSE because they did not understand how to do it, so the respondents asked the researcher about the effect of BSE classes on increasing BSE practice. So it is clear that there is a correspondence between theory and the case on the ground. This research suggested to reproductive age women should practice BSE in life to detect the breast cancer earlier.

The results show there was a difference of knowledge before and after education of BSE. The high level of knowledge will have an impact on the behavior change process that will be carried out in connection with the problems it faces. Someone who has high knowledge in a matter will easily accept better behavior, on the other hand, someone who has low knowledge will find it difficult to accept new behavior properly (Notoatmodjo, 2010) Knowledge is an impression in the human mind as a result of the use of his five senses. Knowledge is everything that is known based on the experiences obtained by every human being (Olfah et al., 2013).

The previous research by Fitra (2013) found that there was an effect of health education on reproductive health knowledge in adolescents at SMA PGRI 03 Purwakarta. There is an increase in knowledge between the pre and posttest carried out. According to the researchers' assumption that knowledge influence students to be able to understand more about health, especially about breast cancer with early detection of breast cancer. Many adolescent girls cannot practice 
BSE because they do not understand how to check BSE even though BSE is a fairly easy way to do it. Education about BSE would be very useful to increase their knowledge so the practice will be ok.

The results show there was a difference of practice before and after education of BSE. BSE measures are very important to implement, because it has been proven that almost $85 \%$ of breast disorders are first discovered by sufferers through the correct application of BSE (Olfah et a.I, 2013). So that BSE can be said to be an effective way to detect breast cancer early. BSE is also easy to do and can be applied by women of all ages. Researchers assumed that the practice of BSE is still less due to the low knowledge about how to practice BSE.

\section{CONCLUSION}

This research shows that there was an increasing of knowledge regarding BSE and practice of BSE after BSE class. Educational institutions can improve the capacity and quality of education so that the information on the results of this research can be used as additional material to enrich knowledge and the need for midwifery references on breast cancer knowledge and BSE practice. It is hoped that this research can be developed further and can conduct research by making a more complex analysis so that it includes a larger number of samples. The midwife needs to improve the knowledge of reproductive age women and educated them to practice BSE in order to prevent breast cancer.

\section{REFERENCES}

American Cancer Society. (2014). Cancer Facts \& Figures 1-72. https://doi.org/10.1177/0300985809357753

Andita, U (2016). Pengaruh Pendidikan Kesehatan SADARI dengan Media Slide dan Benda Tiruan Terhadap Perubahan Pengetahuan WUS. Jurnal Promkes, 4(2), 177-187

Bustan, M. N. (2007). Epidemiologi Penyakit Tidak Menular. Jakarta: PT Rineka Cipta.

Bauty. D (2017). Pengaruh Pendidikan Kesehatan Tentang Deteksi Dini Kanker Payudara Terhadap Kemampuan Melaksanakan SADARI Pada Ibu PKK di Kelurahan Tlogomas Malang. Nursing News, 2(3).

Damayanti R, (2017). Pengaruh Pelaksanaan Pemeriksaan Payudara Sendiri (SADARI) Terhadap Pengetahuan dan Kemampuan Siswi Dalam Upaya Deteksi Dini Kanker Payudara di SMP NEG.1 Sibulue KAB. Bone. http://digilib.unhas.ac.id/uploaded_files/temporary/DigitalCollection/NzI5MmYwZDM0ZjcyZGRhODE1ZmUwYmViMzAzYzNj NTFhOTc4M2FkNw==.pdf. Diakses pada diakses pada tanggal 18 Desember 2019.

Fitra, N. A. (2013). Pengaruh penyuluhan terhadap peningkatan pengetahuan kesehatan reproduksi remaja di SMA PGRI 3 Purwakarta. Doctoral dissertation. Universitas Muhammadiyah Surakarta.

Fitrianti, S \& Haryani, J (2018). Pengaruh Pendidikan Kesehatan Terhadap Pengetahuan Remaja Putri Tentang SADARI di SMAN 1 Kuala Tungkal. Jurnal Psikologi Jambi, 03(01), 52-58

Handayani. (2012). Pengetahuan Remaja Putri tentang Cara Melakukan Sadari. Jurnal: Universitas Diponegoro Semarang. 1(1).

Hasanah, E. (2016). Gambaran Pengetahuan Remaja Putri Tentang Pemeriksaan Payudara Sendiri (SADARI) di SMAN 1 Kendari. KTI. Jurusan Keperawatan. Politeknik Kesehatan Kemenkes. Kendari.

Hidayat, A. A. (2007). Metode Penelitian keperawatan dan Teknik Analisa Data. Jakarta: Salemba Medika

Hidayat A, (2010), Metode Penelitian Kesehatan Paradigma Kuantitatif, Salemba Medika: Jakarta

Kartikawati, C.E. (2013). Awas Bahaya Kanker Payudara dan Kanker Serviks, Buku Baru, Bandung.

Lubis, U. L (2017). Pengetahuan remaja putri tentang pemerksaan payudara sendiri (SADARI) dengan perilaku SADARI. Jurnal IImu Kesehatan, 2(1).

Lusa. (2009). Anatomi dan Fisiologi Payudara. https://www.lusa.web.id/anatomi-dan-fisiologi-payudara/. Accessed 18 December 2019.

Manuaba, I. (2010). Ilmu Kebidanan, Penyakit Kandungan dan KB untuk Pendidikan Bidan. 2nd ed. Jakarta: EGC.

Nasir, dkk. (2011). Buku Ajar: metodologi Penelitian Kesehatan. Yogyakarta: Nuha Medika.

Nasution, M. K. (2013). Teknologi pengetahuan. Dies Fasilkom-TI USU.

Notoatmodjo, S. (2010). Promosi Kesehatan Teori \& Aplikasi. Jakarta: Rineka Cipta.

Notoatmodjo, S. (2010). IImu perilaku kesehatan. Jakarta: Rineka Cipta, 20- 40.

Notoatmodjo, S. (2012). Metodologi Penelitian Kesehatan. Jakarta: Rineka Cipta.

Nugraheni, A. (2010). Hubungan Tingkat Pengetahuan Tentang SADARI Dengan Perilaku SADARI sebagai Deteksi Dini Kanker Payudara Pada Mahasiswi DIV Kebidanan FK UNS. Universitas Negeri Surakarta, Surakarta.

Olfah, Y et al. (2017), Kanker Payudara dan SADARI, Yogyakarta: Nuha Medika

Purwoastuti, E .(2008). Kanker Payudara dan Pengetahuan SADARI. Yogyakarta: Kanisius.

Sari, R.P. (2017). Hubungan Pengetahuan Dengan Perilaku SADARI Sebagai Deteksi Dini Kanker Payudara. Jurnal Ilmiah Kebidanan, 8(2), 57-66

Rasjidi, I. (2007). Kemoterapi Kanker Ginekologi dalam Praktik Sehari-hari. Jakarta: CV Sagung Seto

Ristarolas, T. (2009). Faktor-Faktor yang Mempengaruhi Keterlambatan Pengobatan.

Suastina, A. (2013). Pengaruh Pendidikan Kesehatan Terhadap Tingkat Pengetahuan Siswi Tentang Sadari Sebagai Deteksi Dini Kanker Payudara Di SMA Negeri 1 Manado. Jurnal: Universitas Sam Ratulangi Manado, 1(1). 
Sulistiani, A. (2015). Pengaruh Penyuluhan Kesehatan Terhadap Pengetahuan Remaja Putri Tentang Pemeriksaan Payudara Sendiri (Sadari). Jurnal Kebidanan, 7(01).

Suyanto. (2015). Pengaruh Penyuluhan Terhadap Pengetahuan Dan Sikap lbu Pkk Tentang Pemeriksaan Payudara Sendiri (SADARI). Jurnal: Universitas Tanjungpura Pontianak, 2(2).

Syaful, Y. (2016). Pendidikan Kesehatan Pemeriksaan Payudara Sendiri Terhadap Perilaku SADARI Pada Remaja. Journals of Ners Community, 07(02), 113-124.

U Masturo. (2020). Efektivitas Penyuluhan Kesehatan Tentang SADARI dengan Metode Diskusi Kelompok dan Metode Demonstrasi Terhadap Perilaku WUS dalam Melakukan SADARI. Jurnal ilmiah STIKES Citra Delima Bangka Belitung, 3(2)

Wawan \& Dewi. (2010). Teori \& Pengukuran Pengetahuan, Sikap, dan, Perilaku Manusia (I). Yogyakarta: Nuha Medika.

Yufdel, Y., Indarsita, D., \& Azizah, N. (2017). Pengetahuan dan Tindakan Pemeriksaan Payudara Sendiri (SADARI) pada Remaja Putri di SMK Negeri 07 Medan Tahun 2016. Jurnal IImiah PANNMED (Pharmacist, Analyst, Nurse, Nutrition, Midwivery, Environment, Dentist), 11(3), 148-153.

Yulinda. A \& Fitryah. N (2018). Efektivitas Penyuluhan Metode Ceramah dan Audiovisual Dalam Meningkatkan Pengetahuan dan Sikap Tentang SADARI Di SMKN 5 Surabaya. Jurnal Promkes, 6(2), 116 - 128. 